DOI: 10.17516/1997-1370-0684

УДК 378:330

\title{
New Approaches to the Development of Additional Professional Competences for the Purposes of New Economy
}

\author{
Irina E. Sukovataia, Yuliya I. Cherkasova, \\ Elena V. Dvinskikh and Ludmila K. Vitkovskaya* \\ Siberian Federal University \\ Krasnoyarsk, Russian Federation
}

Received 16.01.2020, received in revised form 27.01.2020, accepted 09.11.2020

\begin{abstract}
As the market participants transform the business models, aspiring to building ecosystems, as digital technologies penetrate into all spheres of our life, as the information flows increase the human capital mobility grows, the list of competences expected to develop in today's university graduates is changing in the global context.

Current trends associated with the economic changes and digitalization require continuous upskilling of future professionals and extension of their competences beyond the curriculum. An international summer school (ISS) is an effective tool for short-term training and acquiring professional knowledge combined with managerial, communication, intercultural skills. The purpose of the study is to identify and review the main factors affecting the transformation of the role played by international summer schools in today's economic education.

Based on the review of universities' learning offerings, the article identifies the learners' need for acquiring additional competencies through international summer schools.

The environmental changes related to the development of a new digital economy and affecting changes in technologies and learning processes at international summer schools in general, were analyzed on the basis of the model for analyzing global trends and changes in paradigms and reskilling patterns.
\end{abstract}

Keywords: digital economics, professional competences, open talent economy, education export, international summer schools.

The research is supported by the grant of the Ministry of Science and Higher Education: Agreement No. 341/19-D of December 3, 2019, for the development and implementation of a higher education programme involving the academic staff of the universities listed in Top 200 of the global ratings (Programme 19).

Research area: economy.

\footnotetext{
(C) Siberian Federal University. All rights reserved

* Corresponding author E-mail address: irasu@yandex.ru; cherkasova.y@gmail.com; dvev66@yandex.ru; lvitkovskaya@sfukras.ru

ORCID: 0000-0001-5946-086X (Sukovataia); 0000-0003-2233-6931(Cherkasova); 0000-0003-2124-6512 (Dvinskikh); 00000003-2188-3343 (Vitkovskaya)
} 
Citation: Sukovataia, I.E., Cherkasova, Yu.I., Dvinskikh, E.V., Vitkovskaya, L.K. (2020). New approaches to the development of additional professional competences for the purposes of new economy. J. Sib. Fed. Univ. Humanit. Soc. Sci., 13(11), 1781-1792. DOI: 10.17516/1997-1370-0684.

\section{Introduction}

Today, the economy is going through a transformation. Due to the new technological revolution, digitalization of all economic and social processes that are gaining momentum it is required to review the basic education paradigms and transform the university models and mechanisms.

While many countries are trying to keep up with the economic, environmental and social transformations, including technological achievements, changes in climate and migration, it becomes clear that intellectual capital is becoming the most precious asset of our time that promotes innovative development of the regions (Agrikova et al., 2019, Popodko et al., 2019). Besides professional competences and skills (hard skills), the core of the intellectual capital in the time of digital economy is formed by digital skills (data analysis, computer-aided learning, artificial intelligence, programming etc.) and soft skills (problem solving, adaptivity, operational and critical thinking, stress resistance, empathy and emotional intellect, self-learning based on the Life-Long Learning principles (LLL), cultural diversity etc.) that are sought for more and more.

Even though academic degrees and/or qualifications still have the attention of employers, the requirements for such are not as strict as before, because companies are getting more interested in the modern skills, competences and work experience. Large companies like Google, Apple, Starbucks and IBM tend to choose candidates based on their skills and competences, not their academic degrees or base education (bachelor's, master's degree or MBA) that were intended to demonstrate the readiness of such candidate for work. Moreover, in the year 2017 nearly 17\% of IBM employees in the USA did not have a bachelor's degree (Sean R. Gallagher).

Export of education is listed among the major branches of export of the top countries of the world: in the USA, education is the seventh exported product, and in Australia it is the third, after iron ore and coal. There is a direct macroeconomic profit from the influx of intellect. The UK todays gets around $\$ 30$ billion from foreign students and the USA gets $\$ 39$ billion, without the economic profit from the activity of the graduates who chose to stay in the country after their studies. In Australia, an education expert brings a profit of $\$ 25$ billion. At the same time, the entire consolidated budget of higher education industry of Russia counts approximately $\$ 15$ billion (Barton Carlyle).

It is obvious that today the competitive capacity of universities is determined by the innovations introduced into education. Construction of a modern system of professional education aligned with the current requirements is one of the priorities of the state. In the year 2019 alone, the budget of the "Education Development" national programme ${ }^{1}$ exceeded 458.6 billion roubles, in 2020 this figure is expected to rise by $40 \%$ to reach 644.3 billion roubles, and the major share of this amount is assigned to the "Professional Education Development" subprogramme.

The key objective of the "Export of Education" federal project run under the "Education" national project is to increase the attractiveness and competitive capacity of Russian education in the international education service market to expand the non-resource exports of the Russian Federation.

The implementation of this project is expected to make Russian education programmes more attractive for foreign citizens, improve the conditions of their stay in Russia during studies, improve the Russian education brand awareness and its status in the international education market, and, eventually, increase the revenue from the education service export manyfold.

\footnotetext{
Approved by the Decree of the Government of the Russian Federation No. 376 dated 31.03.2017.
} 
The project foresees the development of new joint education programmes in English, including summer education courses for foreigners. As a result of the project, the number of intramural foreign students at Russian universities is supposed to grow from 220 thousand people in 2017 to 710 thousand in 2025, and the number of foreign participants of the online courses organized by Russian educational institutions is expected to increase from 1,100 thousand people to 3,500 thousand people. The revenue from the export of Russian education is supposed to increase more than five-fold, exceeding 373 billion roubles in 2025 (Volkov, Mel'nik, 2019).

The listed state projects form a superstructure of the current systems of education budgeting. The programme implementation is assessed by the additional competences within the priority fields of knowledge acquired by the learners; therefore, the programmes are based on the complementary approach within the competence-based model of higher education.

Today, the international labour market changes at a much greater pace than the creation of new educational programmes relevant in the current economy.

As the market demand for skills develops faster than the educational institutions could possibly imagine, many of them work to maintain the relevance and quality of their programmes, at the same time developing and promoting new flexible ways of getting higher education, seeking partnership with other stakeholders, including employers, industries, and educational institutions.

Under the education internationalization policy, the educational institutions strengthen their international programmes both in the scape and the complexity: we see more and more universities establishing their offshore satellite campuses, double degree programmes, educational programmes in foreign languages, modify the admission rules for foreign students, offer online courses and international internships, develop a great number of shortterm educational programmes, including international summer and winter schools (ISS).
Today's university students face the need for acquiring additional competences not foreseen by their basic curriculum. On one hand, they are aware of different ways of getting a degree and the skills they may need for career building, and adjust their education to the new open talent economy, where the shortterm programmes and courses, vocational education, trainings and life-long learning are considered as essentials for the modern labour market.

The students may solve this problem quite efficiently by taking additional education courses, including summer and winter schools where they can both acquire new professional skills and expand their academic and business network, exchange cultural experience etc.

\section{Theoretical framework}

Today's tendencies resulting from the changes in the economy and digitalization required future specialists to continuously upgrade their skills and to expand their competences beyond the educational programmes. An open economy which allows unrestricted flow of people, capital, goods and services across its borders (The Economist), came and introduced its jobs, non-traditional career opportunities, and technological solutions.

The global megatrends are driving everything, including the new open talent economy. The open talent economy is a relatively new term introduced by Deloitte, defined as "a collaborative, transparent, technology-enabled, rapid-cycle way of doing business... when employers and employees now seek each other out on a playing field that is broader and more level than ever before" (Deloitte).

Aware of these tendencies, today's students are ready to look outside the traditional concept of learning, and, though they still accept the value of formal education, they also realize that there are different ways of getting the skills and competences they need for a successful employment and/or improvement of their career opportunities after the employment.

Moreover, the majority of the stakeholders of the global market understand the importance of investing into one's education throughout the career. It opens a huge opportu- 
nity for the education providers to develop and offer new education solutions for acquiring additional competences beyond the curriculum required to cater the needs set by the new economy.

Today's students do not restrict themselves to their university degree programmes when it comes to the development of basic and additional competences; they also gain the skills and competences required for successful employment from the great variety of available online platforms and short-term education programmes of the foreign universities. More and more often we see today's students applying for participation in a wide variety of international summer schools (ISS).

Universities and colleges have a real capacity of expanding their academic offerings by providing short-term courses, advanced training programmes, trainings and short-term holiday education programmes including summer and winter schools (ISS) that are quite popular among the modern generation of students.

\section{Statement of the problem}

The struggle for talents and attraction of international students are the key drivers of innovations, scientific discoveries and new business development. The top universities and national economies of the world are already showing interest in the future intellectual and technological elite. According to the experts, such talents constitute approximately one third of six million mobile students (Volkov, Mel'nik, 2019). The competition between them causes a rapid increase in the number of different scholarship programs, contests, and grants, expansion of the educational programme offerings from online courses to combined learning, internship, dual degrees etc.

UNESCO claims that Russia is one of the leaders in the global market of educational services and that its potential is growing: in the year 2013, the Russian Federation hosted around $3 \%$ of the total number of foreign students (ranked $6^{\text {th }}$ among all education service exporting countries), while in 2018, this figure reached $7 \%$ ( $7^{\text {th }}$ place $)$. However, Russian education still remains unattractive. Even the positive tendencies in the ranking of our univer- sities in the global ratings do not attract more foreign students.

To achieve the goal set by the "Export of Education" project, and, of course, to win the elite students, it is necessary to change the international positioning and general behaviour of the Russian universities, as well as governmental regulation of their activities (Volkov, Mel'nik, 2019).

The majority of domains, from agriculture to IT, are set within the global market and technological context. Today's students are eager to develop their competences almost in all the available professional domains. The majority of them do it along with their university studies by attending short-term courses, trainings, seminars, massive open online courses (MOOC) etc. Short-term education programmes run during holidays, such as summer and winter international schools (ISS), are among the most popular and effective way of developing additional competences beyond the basic curriculum.

Summer schools remain an important tool for the universities to facilitate the internationalization process, promotion of their international reputation, and attraction of foreign students, since ISS are becoming a big business for universities in the United States, Europe, China, and South Africa.

Despite the many years' experience of admitting foreign students to the summer and winter schools of the Russian Federation, in their everyday practice the majority of Russian universities prefer using very few models, patterns and mechanisms for efficient organization of simmer and winter schools for foreign students and potential applicants from abroad.

To expand their audience, the universities need to assess the ISS models as efficient short-term education tools that combine the opportunities of acquiring professional, IT, and "soft skills" sought for by the new open talent economy.

In the light of the foregoing, the comparative analysis of ISS models in the global, national, and regional contexts is necessary for understanding of their development trends and the development of new efficient strategies and actions for the organization of ISS focused on 
the development of new competences, as well as improvement of the existing and implementation of new ISS models in the highly-competitive educational environment.

4. Methods: presentation of the applied research methods.

For the classified description of the variety of modern ISS, for the presentation of their typology and models from the point of view of the development of additional competences in the global, national, and regional contexts, a comparative analysis of the foreign and Russian ISS was carried out.

The study was based on the official university websites and the following Russian and foreign educational portals: universities

- Official websites of the top foreign

- Official websites of the top Russian universities

- Study Portals: Short Courses portal (www.ShortCoursesPortal.eu) - international platform that presents programmes from over 3,200 universities of the world; according to it, Russia maintains its position in the international educational service market as far as summer and winter school offerings are concerned

- Summer Schools in Europe (www. SummerSchoolsinEurope.eu) - international aggregator platform for summer and winter schools in Europe

- Study in Russia (https://studyinrussia. $\mathrm{ru} /$ ) - website supported by the Ministry of Science and Higher Education of the Russian Federation that aggregates information on the educational programmes offered by Russian universities to foreign citizens.

- Study in Europe (https://ec.europa.eu/ education/study-in-europe/country-profiles en).

As the data found in the mentioned sources may contradict each other, and sometimes the differences are quite significant, the data of short-term educational programmes organized in the summer and winter school formats were integrated, and the repeated elements were excluded from the monitoring process.

The conclusions drawn by the authors are based on the trends in the indicators' development under basic social and economic circum- stances. There is no doubt that the COVID-19 pandemic made a significant impact on the trends of development of international summer schools. Since the pandemic is an exclusive and temporary circumstance, the conclusions of the present paper are formulated regardless of the impact it may make on the studied tendencies.

\section{Discussion}

The global tendencies of higher education development are determined by the rapid change of its landscape caused by the growing international competence, information flows, and digital transformation of the economy and other spheres of life that, in their turn, make an impact on the local changes at the national and institutional levels that occur all around the world and in Russia in particular.

The progress of technologies and automatization have convinced $78 \%$ people of the world that they need to develop their "soft skills"; modern students are eager to acquire the competences and skills the machines and artificial intelligence (AI) are still uncapable of mastering, such as critical thinking, problem solving and creative approach, empathy etc. Over three fourths of the respondents of Pearson's global survey confessed the need for developing such soft skills as creativity, creativity and learning ability, communication and teamwork, ability to act in different intercultural and ethnic contexts, management skills etc. that are gaining more and more importance. In addition to these, a good command of English language is also helpful in the new economy (Pearson, 2019; ICEF Monitor, 2019).

The Pearson's study has proven that the relevance of additional competences and lifelong-learning was recognized in China and India earlier compared to the USA and the UK. In China and India, this tendency is mostly determined by the influence made by the technologies and automatization on the labour market due to their critical significance for the maintenance of stable employment.

Today's learners tend to prefer the "do-ityourself" (DIY) approach to education; they understand the value of professional and shortterm educational programmes and use Internet resources for advanced training. Moreover, 
short-term programmes, courses, boot camps are found to be the most popular choice for acquiring the competences necessary for successful employment and/or career growth: at least twice as many respondents of the poll in several regions of the world (USA, Australia, Canada, Europe, Brazil, China and the Middle East) prefer short-term programmes as the respondents who gravitate to certified university or college courses (Pearson, 2019).

In response to these challenges, universities offer more and more flexible educational solutions designed with respect to the continuous changes in the labour market. For this reason, the international education market has been recently going through a phenomenal growth causing changes in the spectrum and models of short-term educational programmes, including the summer and winter schools being an effective short-term education tool that combines the acquisition of professional, IT and soft skills and competences to cater the needs of the digital economy.

All around the world we witness an incredible growth of summer and winter schools for foreigners (Kureshov, 2010). Jeroen Torenbeek and Edwin van Rest have studied the quality and quantity of modern European summer schools in the international context to arrive at the following conclusions:

- The number of ISS offered in Europe in 2014 has increased by at least $200 \%$ in the last five years;

- Small European countries were ranked incredibly high in the number of offered ISS: in 2013, there were two comparatively small countries in the top 6: the Netherlands (rated $\left.1^{\text {st }}\right)$ and Denmark $\left(6^{\text {th }}\right)$;

- The United Kingdom and Germany also offered a large number of summer courses, followed by Russia and Italy;

- Over $50 \%$ of the European summer school market was provided by $6 \%$ of the major suppliers: the Netherlands, the United Kingdom, Germany, Russia, Italy, and Denmark;

- In 2013, around 40,000 students attended summer school education programmes.

The comparative analysis of data and educational platforms has shown some emerging trends in the changing of numbers and models of the ISS offered on the international market in the last 5 years:

- The number of summer and winter schools offered in Europe today has almost doubled compared to the year 2013 (Torenbeek et al., 2013); the total number has reached 6,286 summer schools by the present moment (Study Portals: Short Courses portal, 2019) (Fig. 1);

- From the point of view of the main leaders, such as the USA, the UK, Australia, Germany, France, and Russia, as far as the number of ISS for foreign students is concerned, the global higher education market situation remains approximately the same, though their proportions among the countries vary. Thus, in 2019, the US had the largest share of summer schools: 2,482; the United Kingdom offered 1,431, Australia - 475, Canada - 130, Germany - 117, Russia -103, France - 85, China - 29 (Fig. 2);

- The leaders in the number of summer school are still the smaller countries: the Netherlands $\left(2^{\text {nd }}\right)$, Denmark $\left(8^{\text {th }}\right)$ and Italy $\left(5^{\text {th }}\right)$;

- From the same point of view, the phenomenon of Ireland appears especially interesting: in 2013, it was the $18^{\text {th }}$ in Europe in the number of international summer schools, but in the last 5 years it has increased the number of its summer and winter schools from 15 to 97;

- France, Germany, and Russia are also listed in the top 10 ;

- New summer schools opened in China, New Zealand, and India (Fig. 2);

- The share of the winter schools, when the studies are parallel to the main academic process, is growing in the system of international schools (Greer, 2020).

This way, in the year 2019 the number of summer schools increased, with an obvious correlation between the number of academic offers for summer and winter schools and the structure of the global higher education market.

Due to the pandemic of COVID-19, in number of summer schools dramatically dropped in the year 2020. Thus, Study Portals offers only 1402 summer schools, the majority of which (349) are in the United Kingdom, 215 schools in the USA, 272 in the Netherlands and 85 in Germany, 66 in Russia and 61 in It- 


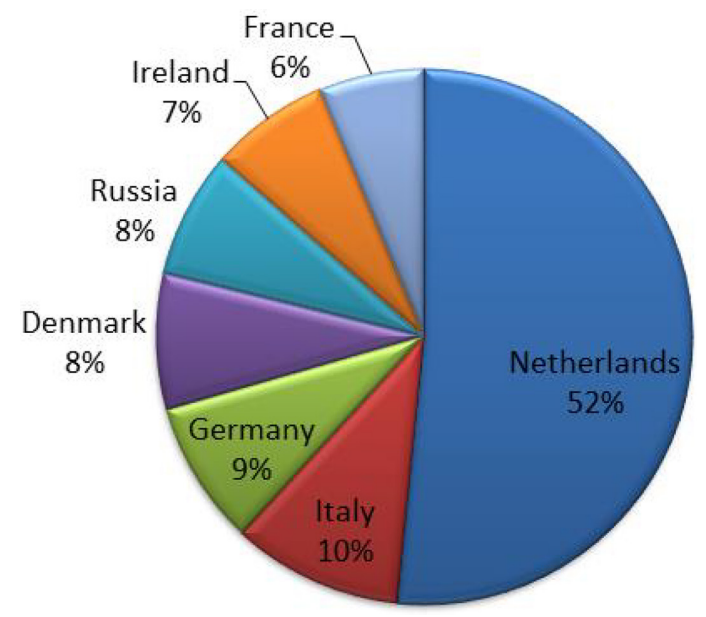

Fig. 1. Number of summer and winter schools in the countries of Europe offered by Study Portals in 2019 (source: Study Portals: Short Coursesportal, 2019, Available at: www.ShortCoursesPortal.eu)

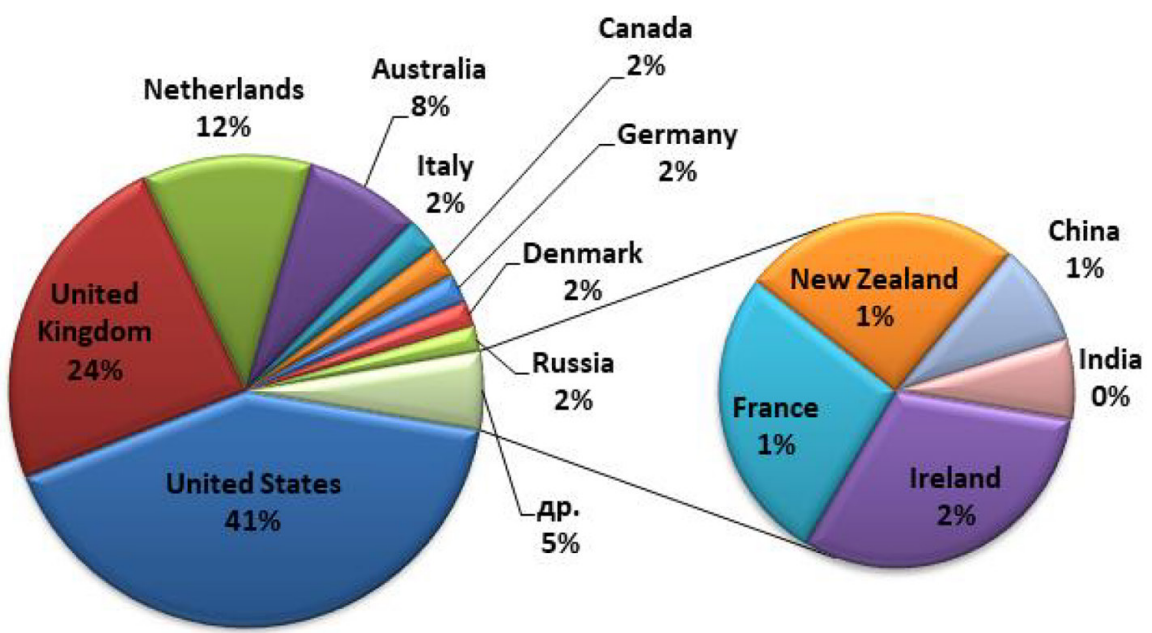

Fig. 2. Number of summer schools offered by Study Portals platform, by countries (source: Study Portals: Short Courses portal, 2019, Available at: www.ShortCoursesPortal.eu)

aly. The dominating share of the schools has switched to online learning.

Today, besides the traditional third semester, more and more American universities offer summer programmes similar to those of the summer schools in Europe and Asia. Almost every university has its summer school model: from hobby courses to full-scale academic modules, a university in the microcosm. Some courses may be dedicated to local language and culture, others are related to the university profiles and their excellence domains, let it be natural science or linguistics. There may be courses of any level, from bachelor's to specialty courses for post-graduates and $\mathrm{PhD}$ students. The experience of the American colleges that offer summer schools for the low-income youth in both academic and supplementary programmes is of special interest (Chastonay, 2016).

In the $21^{\text {st }}$ century, the summer school phenomenon reached Asia where it is rapidly gaining momentum. At the beginning, summer schools were regarded as a source of revenue, 
particularly in China. By now, the Asian summer school model has been aligned with its European analogues, with the focus made on different aspects of the university internationalization strategy.

The academic offers of many universities organized in the ISS form may include different forms of short-term programmes.

Traditional (classical) ISS - are shortterm programmes offered, as a rule, in the summer (winter) months during holidays, by an accredited higher educational institution for people of all education levels, from bachelor's degree to $\mathrm{PhD}$; there is usually a tuition fee (not compulsory) paid to cover the current expenses; courses with ECTS credits.

A summer school may encompass one or several subject courses, usually lasting from one to four weeks, but in some cases may be as long as eight weeks. The students take in-class intensive courses and participate in an activity programme. Amed at the soft skills development, the sociocultural programme is getting more and more importance.

Among the new ISS formats, there are the following: summer university; academic courses; professional and skill courses with the employers; collaboration projects with foreign partner universities; chain summer schools organized by themed networks or new alliances; internationally accredited schools etc. (Chastonay, 2018; Achille, 2018; Molderez, 2018; White, 2015; Landri, 2020; Kedziora, 2019; Ortiz-Marcos, 2016; Browne, 2016).The main distinctive feature of these ISS is the focus on certain learning results and the development of competences combining professional, IT, and soft skills for the new open talent economy.

Based on the monitoring of open internet platforms and the websites of Russian universities, the main features of the summer and winter schools offered to foreign citizens by Russian universities have been formulated:

- The number of summer and winter schools for foreign citizens offered by Russian universities in the international education market has not significantly changed in the last five years: in 2013, 83 schools, i.e. $6 \%$ of the number of European summer and winter schools, were offered on the international educational platforms (J. Torenbeek and E. van Rest, 2014); today, there are only 103 , which makes $8 \%$ of the total number of European summer and winter schools (Fig. 1), and only $2 \%$ of the total number of summer and winter schools in the world (Fig. 2);

- The greatest number of schools are offered by universities in the capital cities; over a half of the summer school market is captured by three main suppliers: Higher School of Economics (HSE), Peter the Great St. Petersburg Polytechnic University (SPbPU), Peoples' Friendship University of Russia (RUDN), ITMO University (ITMO) (Fig. 3);

- Only a few of the top Russian universities may boast the increase in the quantity and quality of the international summer and winter schools they offer to foreign citizens.

In the last six years, the flagship among the Russian universities been People's Friendship University of Russia (RUDN) which offered 40 summer and winter schools for foreign citizens back in 2013 (Torenbeek and Rest, 2014).

The International Polytechnic Summer and Winter School of Peter the Great St. Petersburg Polytechnic University (SPbPU) offers a broad range of courses in engineering and natural science, physics, IT technologies, economics and business, as well as Russian language, culture and Russian civilization. At the moment, the university provides over 30 high-quality summer and winter school modules taught to foreign students in English. After the course, the students get ECTS credits and certificates. Every year. SPbPU welcomes over 500 students representing more than 50 countries of the world.

Higher School of Economics (HSE) is today's leader in the number of summer and winter schools for foreign citizens in a broad range of topics, organization forms and models. Similarly to the largest summer university of Europe, Utrecht Summer University (the Netherlands), the establishment of the HSE International Summer University (https://www. hse.ru/international/summer/) is a unique phenomenon in the Russian summer school system different in its organization form and the scale 


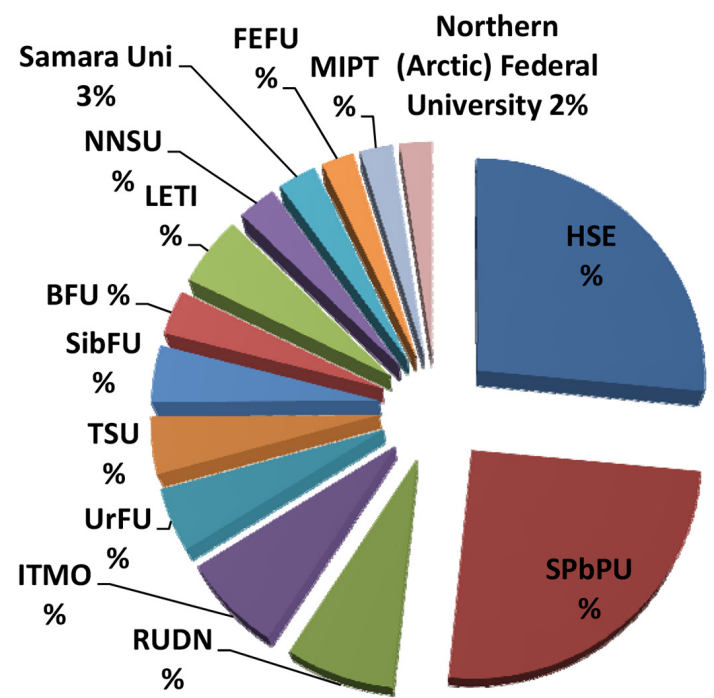

Fig. 3. Number of summer and winter schools at 14 Russian universities

(sources: Study Portals: Short Coursesportal, 2019, Available at: www.ShortCoursesPortal.eu, Summer Schools in Europe (www.SummerSchoolsinEurope.eu), Study in Russia (https://studyinrussia.ru/), official websites of the universities)

as well as territorial distribution between four cities of Russia.

Among other Russian universities, Siberian Federal University (SibFU) is sharing the $6^{\text {th }}$ and $7^{\text {th }}$ places with Tomsk State University, offering a number of international summer programmes including language schools, international summer schools in collaboration with foreign partner universities etc.

One of the successful ISS projects of SibFU is was $V$ International Summer School "New Financial Technologies under the Conditions of Digital Transformation of Economy" (see school page on SibFU website: http://www. sfu-kras.ru/en/education/courses/economic-science, official website: http://mlsh-econ. sfu-kras.ru/) designed for the students interested in the financial aspects of the modern economy.

At the beginning, the school was targeted at the development of additional mathematical simulation, self-identification and self-development technologies and language competences beyond the curriculum of economy students. The five-year experience of the ISS and feedback from its participants showed the need for practice-oriented approach and involvement of potential employers. In 2019, the school was held with active support of the specialists representing the Bank of Russia and Sberbank of Russia. The programme was redesigned with regard to the financial and digital competences, big data analysis, skills, understanding artificial intelligence, design thinking requirements etc. relevant in today's financial market.

A principal innovation was an interactive educational space where every student could share their opinions, check their positions with the top specialists in the professional domain and get immediate feedback from authoritative reviewers. After the studies, the students got certificates (3 ECTS credits).

The summer school programme was intended not only to develop and share the knowledge, but also to encourage mutual understanding between representatives of different cultures. The school participants had a chance to feel the unique atmosphere of Siberian Federal University. Besides the academic programme, the school offered a variety of cultural and sports activities and city tours. All these helped the students open their minds and get integrated in the international academic environment. The school is very popular among the students of Chinese universities; in 2019, it 
was visited by 49 economy students of top Chinese universities.

The analysis of the ISS offered by Russian Universities on the international market today has shown that there is a limited range of types and models in the wide spectrum of available models used by the majority of Russian universities today. The majority of them are traditional Russian language and culture ISS. The new ISS models intended to develop additional competences sought for in the new economy in the middle and in the long run are, in fact, single projects of individual universities, constituting only several per cent of the total number of ISS. For instance: practice-oriented ISS with potential employers: only $6 \%$, ISS organized in collaboration with foreign partner universities: $8 \%$, schools run in several cities: $5 \%$ etc. ISS in foreign languages constitute only $56 \%$ of the total number.

Summer schools are becoming an important tool for universities to advance their internationalization, to improve their international reputation, to attract foreign students and raise the revenue. There is a great variety of models for summer schools and courses designed for different purposes; therefore, it appears relevant to develop a methodological base for the development, promotion and organization of ISS as effective tools for the development of additional competences, combining professional, IT, and soft skills required for the successful career in the global labour market.
The development of a methodological foundation for the organization of summer and winter schools for foreign citizens at Russian educational institutions and its further implementation may become an efficient tool for solving the problem of increasing the share of foreign students, improving the attractiveness of Russian educational programmes for foreign citizens at all levels (bachelor's, specialist's, master's degrees, advanced training) are the key solutions to the problem the universities are facing nowadays.

\section{Conclusion}

Human capital today determines the competitive advantages of the states, and the export of education through different channels including international summer schools becomes an indicator of the high intellectual potential of the territory and a catalyst for economic development.

International summer schools are a unique academic offer of the modern universities, a highly efficient tool of short-term education that combines the opportunities of getting professional knowledge and communicative, intercultural, management skills in the continuously changing conditions of the labour market. Summer and winter schools are now perceived as a unique laboratory of innovative education. The short-term intensive ISS courses open new opportunities for students and lecturers to get additional skills and competences sought for in the long run.

\section{References}

Achille, C., Fassi, F., Mandelli, A., Fiorillo, F. (2018). Surveying cultural heritage: summer school for conservation activities. In Applied Geomatics, 10, 579-592. Available at: https://link.springer.com/article/10.1007/s12518-018-0225-3

Agrikova, E., Voronina, M., Kashina, E., Levchenko, V. (2019). Transmedia skills as an integral part of the $21^{\text {st }}$ century professional: Structure and development. In Astra Salvensis, 13, 327-342.

Aigner, B., David, V., Deinhofer, M.M., Kratschanova, A., Veigl, D.I.C. (2014). The AsTeRICS Academy for cross-cultural education in assistive technologies. 13th International Conference on Information Technology Based Higher Education and Training. Available at: https://s3-us-west-2.amazonaws.com/ieeeshutpages/xplore/xplore-ie-notice.html?\#

Barton, Carlyle. (2019). No Going Back: Exploring new horizons in global education (Part 2). Available at: bartoncarlyle.com

Browne, D. (2016). Summer learning that sticks. In Phi Delta Kappan, 98, 15-20. Available at: https:// journals.sagepub.com/doi/10.1177/0031721716681771 
Chastonay, P., Mpinga, E.K. (2018). The Geneva University Global Health and Human Rights Summer School: A 5-Year Intercultural Collaborative Experience. In Frontiers in Public Health, 6, 128. Available at: https://www.frontiersin.org/articles/10.3389/fpubh.2018.00128/full

Greer, S. (2020). Training for live art: process pedagogies and New Moves International's Winter Schools. In Theatre, Dance and Performance Training. 11, 214-228.

ICEF Monitor (2019). Available at: https://monitor.icef.com/2019/05/growing-importance-non-degree-credentials/, https://monitor.icef.com/2019/10/global-survey-reveals-growing-interest-in-shorter-programmes-and-lifelong-learning/

Institute for International Education (IIE), Project Atlas (2017). Available at: www.iie.org

Kedziora, W., Touchan, R., Meko, D., Szyc, K., Wojtan, R., Bijak, S., Tomusiak, R. (2019). The 2019 International Summer School "Tree Rings, Climate, NaturalResources, and Human Interactions," Warsaw, Poland. In Dendrochronologia, 58, December, 125631.

Kureshov, V.A. (2010). Universitet na puti k mezhdunarodnoy integratsii [University on the way to international integration]. In Vysshee obrazovanie v Rossii [Higher Education in Russia], 1, $56-62$.

Landri, P., Grimaldi, E. (2020). Summer School in European Education Studies as a laboratory for educational research in Europe. In European Educational Research Journal, 19(3), 173 -182.

Molderez, I., Brabant, K., Lambrechts, W. (2018). A Summer School for Sustainable Management as a Strategy for Fostering Collaborative Competencies to Be Able to Build Multi-Actor Partnerships. In Leal Filho W. (eds) Handbook of Sustainability Science and Research. World Sustainability Series. Springer, Cham. https://doi.org/10.1007/978-3-319-63007-6_52

Obuchenie tsifrovym navykam: global'nye vyzovy i peredovye praktiki. Analiticheskiy otchet [Teaching digital skills: global challenges and best practices. Analytical report]. Moscow: Sberbank Corporate University, 2018.

Opportunity for Higher Education in the Era of the Talent Economy. Available at: https://www.pearson.com/content/dam/one-dot-com/one-dot-com/global/Files/news/gls/Pearson_Global_Learner_Survey_2019.pdf

Ortiz-Marcos, I., Fransson, T., Hagstrom, P., Mazorra, J. (2016). Project Based Learning in an International Context in Sustainability and the Global Economy. TIME European Summer School: A Truly European Learning Experience. In International Journal of Engineering Education, 32 (5), 2284-2293.

Pearson Global Learner Survey. Available at: https:/www.pearson.com/content/dam/one-dot-com/ one-dot-com/global/Files/news/gls/Pearson_Global_Learner_Survey_2019.pdf

Popodko, G.I., Zimniakova, T.S., Ulina, S.L., Sumina, E.V., Bukharov, A.V. (2019). Modelling the innovative performance of resource areas: analysis of 22 Russian regions. In Regional and Sectoral Economic Studies, 19, 2, 57-68.

Sean, R. Gallagher (2018). Educational credentials come of age: A Survey on the Use and Value of Educational Credentials in Hiring December 2018. Available at: https://www.northeastern.edu/cfhets/wp-content/uploads/2018/12/Educational_Credentials_Come_of_Age_2018.pdf

Study in Europe. Available at: https://ec.europa.eu/education/study-in-europe/country-profiles_en

Study in Russia. Available at: https://studyinrussia.ru/

Study Portals: Short Courses portal. Available at: www.ShortCoursesPortal.eu

Summer Schools in Europe. Available at: www.SummerSchoolsinEurope.eu

The Economist, Economist Online Business Terms Glossary (Retrieved June 14, 2013). Available at: http://www.economist.com/economics-a-to-z/o\#node-21529641

The Open Talent Economy. Available at: https://www2.deloitte.com/global/en/pages/human-capital/ articles/open-talent-economyl.html

Torenbeek, Jeroen, and van Rest, Edwin (2014). Summer Schools in Europe, published by the European Association for International Education (EAIE), November 2014 EAIE.

UNESCO (2017). 
Volkov, A., Mel'nik, D. (2019). Zachem Rossii inostrannye studenty [What Russia needs foreign students for]. In Vedomosti, April 09, 2019. Available at: https://www.vedomosti.ru/opinion/articles/2019/04/09/798618-zachem-rossii-studenti

White, F., Crowley, L. (2015). The international summer school experience: a worthwhile challenge. In Law Teacher, 39-59. https://www.tandfonline.com/doi/full/10.1080/03069400.2014.988461

\title{
Новые форматы развития дополнительных профессиональных компетенций для новой экономики
}

\author{
И.Е. Суковатая, Ю.И. Черкасова, \\ Е.В.Двинских, Л.К. Витковская \\ Сибирский федеральныий университет \\ Российская Федерачия, Красноярск
}

\begin{abstract}
Аннотация. Преобразование участниками рынка своих бизнес-моделей и стремление к созданию экосистем, проникновение цифровых технологий во все сферы жизнедеятельности, рост информационных потоков, а также высокая мобильность человеческого капитала изменяют в мировом контексте компетенции, которые должны формироваться у сегодняшних выпускников вузов.

Современные тенденции, связанные с изменениями в экономике, цифровизацией, требуют от будущих специалистов постоянного обновления навыков и расширения перечня компетенций за рамками образовательных программ. Международная летняя школа (МЛШ) является эффективным инструментом краткосрочного образования, сочетает возможности получения профессиональных знаний и управленческих, коммуникационных, межкультурных навыков. Целью проведенного исследования стало определение и обзор основных факторов, влияющих на трансформацию роли международных летних школ в современном экономическом образовании.

В данной статье на основе обзора академического предложения университетов выявлена потребность со стороны обучающихся в получении дополнительных компетенций через участие в международных летних школах.

Изменения внешней среды, связанные с формированием новой цифровой экономики и влияющие на изменение технологий и процессов обучения в международных летних школах в целом, проанализированы на основе модели анализа глобальных трендов и изменений парадигмы и моделей обучения новым компетенциям.
\end{abstract}

Ключевые слова: цифровая экономика, профессиональные компетенции, экономика талантов, экспорт образования, международные летние школы.

Исследование поддержано грантом Министерства науки и высшего образования РФ: договор № 341/19-Д от 03.12.2019 на выполнение работ по разработке и реализации образовательной программы высшего образования с привлечением научнопедагогических работников из университетов, входящих в топ-200 предметных глобальных рейтингов (Программа 19).

Научная специальность: 08.00.00 - экономические науки. 